\title{
エジプト・カイロにおける都市型隊商施設(ワカーラ)の 建築的実態と歴史的変化について ON ARCHITECTURAL FEATURES AND HISTORICAL CHANGES OF WAKALA-S IN CAIRO, EGYPT
}

\author{
山田幸正* \\ Yukimasa YAMADA
}

\begin{abstract}
This paper refers to a few observations on architectural features and historical changes of wakala-s in Cairo, reporting some results based on a field survey of 73 existent examples in 1994 and 1995. Wakala-s in the Mamluks period were constructed rather on a large scale and well-organized, having a groin vaulted entrance passage-way and a trifoliate stalactite portal, as probably state facilities. From the 16 th century onward, under the Ottoman, while the wakala-s remained to have the same arrangement of cells with vaulted alcoves, they adopted some peculiar features like a segmental vaulted portal and corbelled salients, playing commoner roles as urban commercial facilities.
\end{abstract}

Keywords: Urbanism in Islam, Caravansarai, Commercial facilities, Trade, Mamluks, Ottoman

イスラムの都市性, キャラバンサライ, 商業施設, 交易, マムルーク朝，オスマン朝

\section{1.はじめに}

10世紀後半に創建されたカイロ(カーヒラ)は、アラブ・ イスラーム世界における「中心地」のひとつとして繁栄を 享受してきた。特にマムルーク朝治下の 13 世紀後半から 14 世紀前半には、紅海から上エジブトを通るルートが主要な 交易路となり、安定した農業生産にも恵まれ、経済的な繁 栄期をむかえた。その後べス卜流行などで一時衰えをみせ、 16世紀はじめにはオスマン帝国に属する一地方都市となっ たが、コーヒ一貿易などによって徐々に回復した。そのよ うな経済的な活動を支えてきたのが、「ワカーラ」と呼ば れる都市立地型の隊商交易施設である。

ワカーラは一般に「キャラバンサライ」と総称されるも のに属するが、この呼称は現在、エジプトでしか使われて いない。また、他の用語が郊外交易路上のものにも併用さ れるのに対し、ワカーラは都市に立地するものに限定して 使用される ”。「ワカーラ wakâla」という語は、「代理を する」を意味するアラビア語起源で、レバノンの14世紀前 半の碑文のなかに「dâr al一wakâla」という熟語としてみら
えるのが、碑文における初出例である2゙。ここでは「バイ ト・アル・マール bayt al-mal」という国家機関に関連した 施設で、国家から委任された代理人（ワキール wakîl）に よって管理された公的な會庫、あるいは物品入市税なよ゙を 徵収する税務官庁の出先であった。この種の施設として歴 史上カイロにおける最古の実例は、マムルーク朝アミール・ クースーンが1330年頃建設したものといわれる

高度に発達した商業社会であるイスラーム都市において、 かつては重要な役割を演じたにちがいない、こうした都市 型隊商施設について、特にそれらの建築的実態について、 これまで十分に解明されているとは言い難い4)。そこで本 稿では、カイロに現存するワカーラを取り上げ、おもに現 地調查より得た資料に基づき、それらを建設年代に沿って 整理し、その建築的な諸特徽を明らかにするとともに、そ の歴史的変化をたよ゙りたい。

\section{2. 調查の概要と研究対象}

19世紀初頭に編纂された「エジプト誌」 ${ }^{5)} 19$ 世紀末の

\footnotetext{
* 東京都立大学工学部建築学科 助手 $\cdot$ 工修 Research Assoc., Dept. of Architecture, Faculty of Engineering, Tokyo
} Metropolitan Univ., M. Eng. 
アリー・ムバーラクの「地誌」など ${ }^{6)}$ から、レイモンらは オスマン朝期におけるカイロ（ブーラーク地区を含む7） に所在した405のワカーラを列挙し、そのうち393件につい て地図上に概略の位置を示している ${ }^{8)}$ 。これらの既往研究 にもとづき行なった $1994 / 95$ 年の踏查の結果、総数 73 棟の ワカーラが確認された ${ }^{91}$ 。

地域ごとのみると、オスマン朝期に245件あったとされる カーヒラ内で49例、60件を数えたズワイラ門から南でハリ ージュ（現ポート・サイード通り）以東の地域で 7 例、32 件あったハリージュ以西の地域ではわずかに 1 例が、それ ぞれ遺存する。また、マムルーク朝期以来のカイロの外港 であったブーラーク地区には、現在16例のワカーラがみら れる（オスマン朝期45件）。

このように多数のワカーラがすでに失われただけでなく、 現存する73例の保存状態もけっしてょくはない。ほぼ完全 な姿であるのは11例のみで、うちカーイトバーイ(No. 5;以下 橎战查No. )、バーザルア(14)、グーリー（45)など 7 例がオス マン朝以前に属するものである。2階以上の上階が失われ ているものが多く、ファサードや 1 階中庭周囲の状況が分 かるものは、ハサン・グムア (2)、ザハビー(28)、シャラー イビー(48)、ハルヌーブ(58)など30例ある。カイロで最古 とされるクースーン（8）をはじめ、アッバース・アーガー (15)、ハサン・パーシャー(58)など7 例はわずかに門や入 口部分しか残っていない。

\section{3. 建築的実態}

隊商交易で取り扱われる商品の保管、陳列、壳買取引な ど商業業務のための施設であるワカーラは、その上層階に ラブァ $\mathrm{rab}^{\circ}$ と呼ばれる集合住宅が併設されている場合が多 い。ラブァは基本的に家族の定住用として賃貸されるもの で、単独で建つもののほか、ワカーラや店舗など商業施設 と複合化されるもの、宗教的複合体の一部をなすものなど がある。ワカーラの上階に載るラブァは、下階の業務用部 分とアクセスを分け、ほぼ完全に分離されているものが多 い。本稿では商業施設としてのワカーラを主題とすること から、ラブァ（集合住宅）の部分については考察対象から 除き、㧤もに商業目的に使用された $1 \sim 2$ 階部分を中心と して考察をおこないたい10〉。

表-1 マムルーク朝後期の現存ワカーラ（～1517年）
現存する73例のワカーラを、(1)1517年のマムルーク朝滅 亡以前、(2)それ以後17世紀末までのオスマン朝支配前期、 (3)18世紀のオスマン朝支配後期、(4)19世紀以降の近代期、 以上 4 期にわけて述べる。

【3-1 マムルーク朝後期の実例】16世紀初頭までに属す る遺構は、9例である（表-1）。

ナ゙スル門の南側に立地するカーイトバーイ(No. 5)は、ブ ルジー・マムルーク朝第21代スルターンによって1480/81年 に建造されたもので、ほぼ全体像のわかるカイロ最古の実

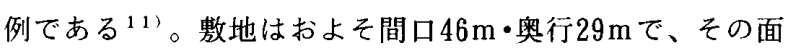
積は $1,500 \mathrm{~m}$ をやや上回る。街路側ファサードは比較的保 存状態はよく、一部は 5 層まで現存する(図-1)。建物の南 東隅部にはサビール・クッターブ（公共給水場およびコー ラン学校）が付属した（崩壊）。また東側に10戸、南側に 4 戸の店舖（およそ間口 $2.5 \mathrm{~m}$ ・奥行 $3 \mathrm{~m}$; 現在一つの契茶 店を除き、すべて工房）が街路に面して並んでいる。

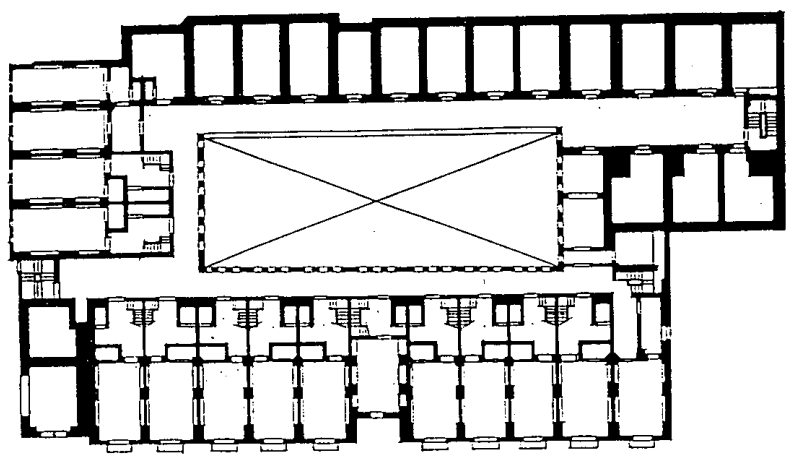

2 階平面図

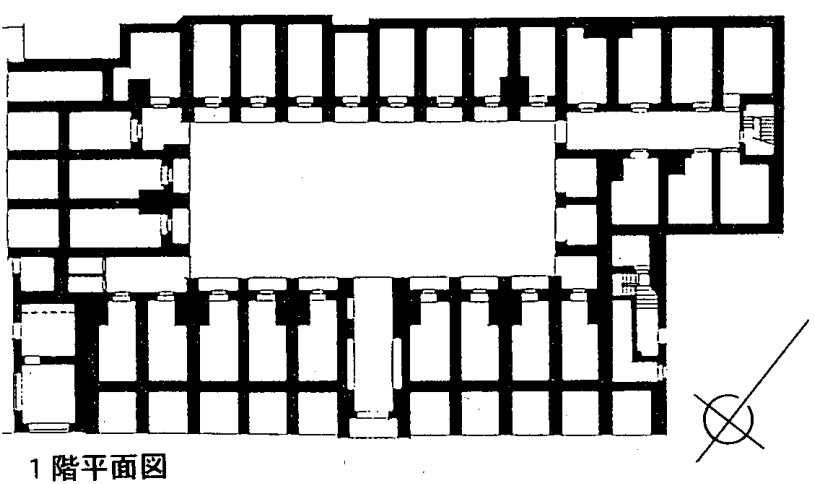

図-1 カーイトバーイ(No.5)

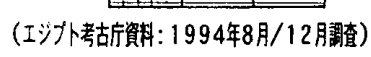

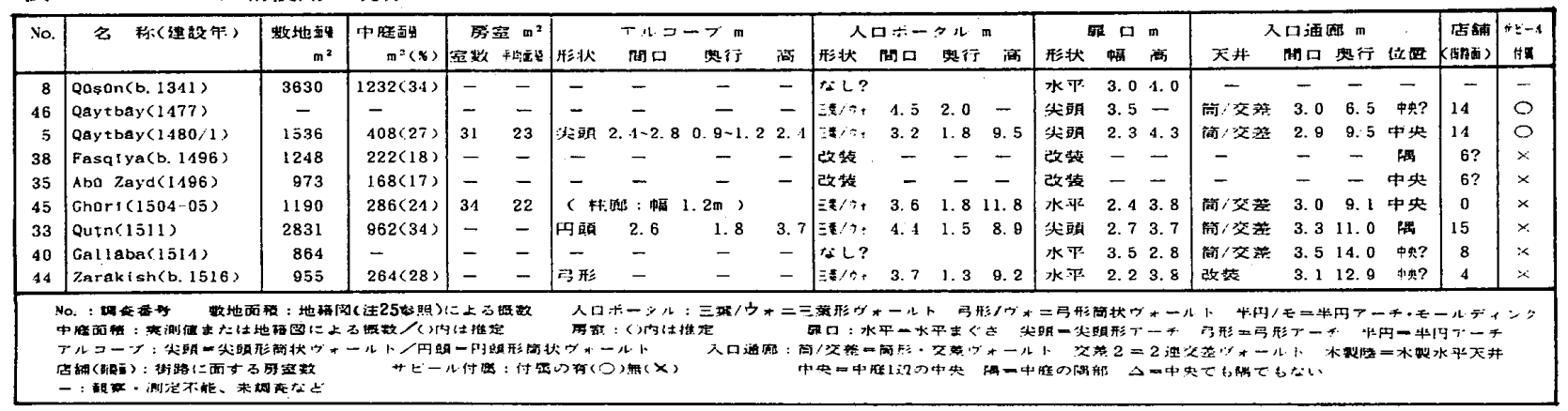




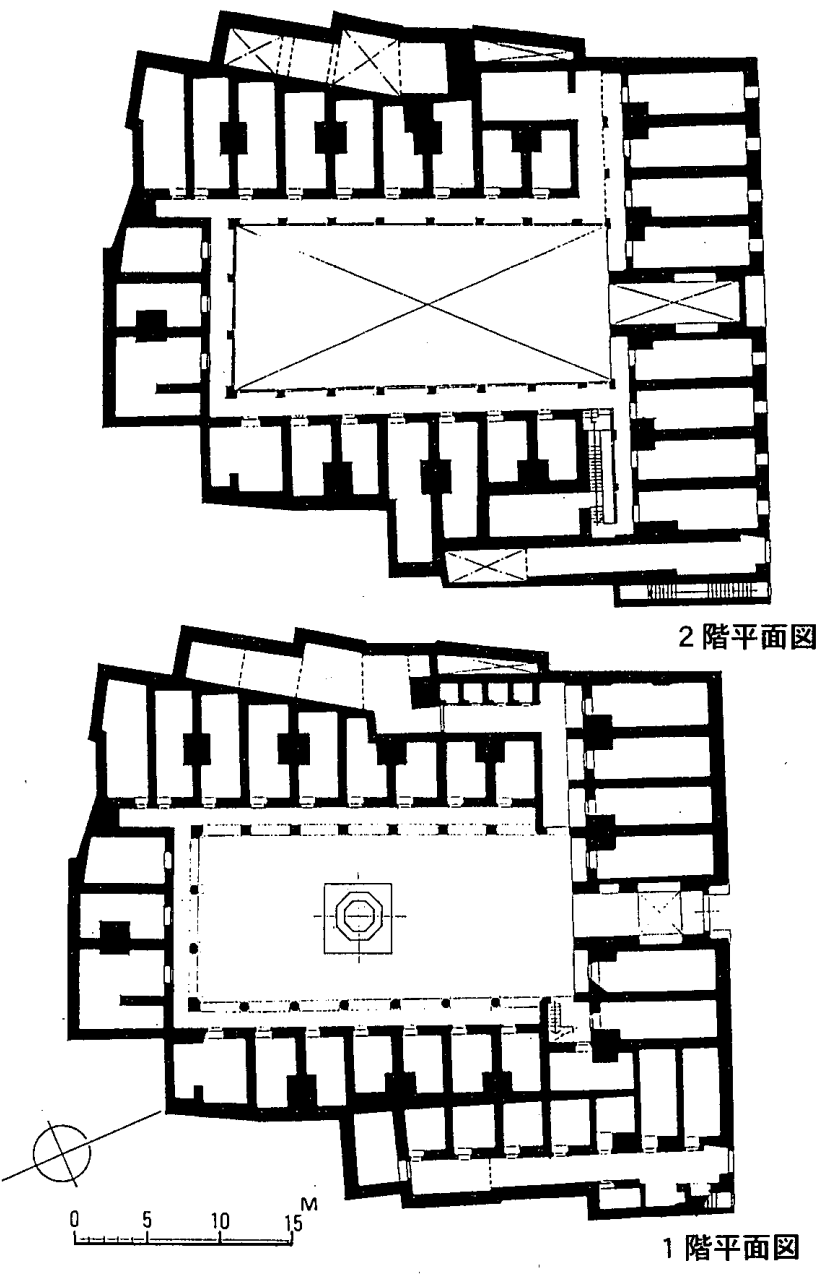

図-2 グーリー(No.45)

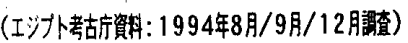

入口ポータルはマムルーク朝後期に独特な垂直性を強調 したイワーン状をなし、建物のほぼ 3 層分の高さ $(9.5 \mathrm{~m})$ に 上下 2 部構成の三葉形ヴォールトが覆っている(図-21)。隅 にムカルナスをおきアーチを交差させた下部に、尖頭形を 正面にみせた小さな半ドームを冠した上部とからなる。人 口通廊はおよそ間口 $3 \mathrm{~m}$ ・奥行 $9.5 \mathrm{~m}$ で、高さ約 $6.5 \mathrm{~m}$ の尖頭 形筒状ヴォール卜で覆われている。ただし、韭口すぐ内側 には交差ヴォールトがかかり、中心の八角形から8本の棱 線が描かれている。建物の南北側それぞれに、正面人口之 は別に簡素な戸口があり、上階への階段が備わる。

䄪 $26 \times 11 \mathrm{~m}$ の南北に長い長方形の中庭に面して配された 計19室の小部屋（房室 ${ }^{12)}$ )のそれぞれには、奥行 $1 \mathrm{~m}$ ほど の尖頭形筒状ヴォールトがかかる前室部（アルコーブ $\left.{ }^{13)}\right)$ をもつ。房室もアルコーブ同様のヴォールトで覆われてい る。2 階西側には 1 階房室と同様の筒状ヴォールトのかか る部屋が並ぶ。扣そらくこれらは北西隅の階段(非現存)を 通じ、1 階と直接つながった業務用室として使われていた のではないだろうが4?。

マムルーク朝末期のスルターンにより 1504/05年 建設さ れたグーリー(No. 45)は、アズハル・モスクに隣接した市街 地中心部に立地する ${ }^{15)}$ 。そのためか、建物の外形輪郭線は
極めて不規則で、 $1200 \mathrm{~m}^{2}$ ほどの敷地面皘は前例よりやや小 さいが、内部の部屋数は逆に多い(図-2)。街路側 1 階に店 舗などを設けず、建物下層は切石積みの壁面が続き、閉鎖 的である。中央の入口とは別に、東側に $2 つ$ つさな戸口 が設けられている。アーチ形の戸口は奥に通路が続き、も う一方の矩形のものは 3 階への階段に通じている。

入口ポータルは前例以上にムカルナスを多用した三葉形 ヴォールトがかかり、その高さは建物の 4 層分(約 $12 \mathrm{~m})$ あ る(図-20)。前例と奥行は変わらないが、間口は $1 \mathrm{~m}$ ぼ゙狭 く、その分ヴォールトの垂直性がさらに強調されている。 しかし、内開き戸の備わる屝口は水平まぐさで高いもので はない。幅 $3 \mathrm{~m} ・$ 奥行 $9.1 \mathrm{~m}$ ほどの入口通廊は高さ $6 \mathrm{~m}$ 以上 の筒状ヴォールトで覆われている。ただし、屝口に近い約 $4.5 \mathrm{~m}$ ほどは、前例と同様の八角形を中心とした 8 本の棱線 をみせる交差ヴォールトとなっている。

中庭はおよそ南北 $26 \mathrm{~m}$ ・東西 $11 \mathrm{~m}$ の矩形で、1階におい て東、南、西辺に八角形の石造ピアが立ち並び、内法幅1.2 $\mathrm{m}$ ほどの柱廊がめぐっていることが、前例との最も際立っ た相違であろう。柱源に面して配されている房室の奥行は

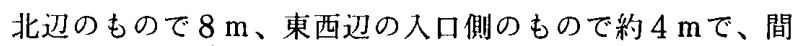
口は一部を除いて、概ね2.8〜 $3 \mathrm{~m}$ である。それぞれの房室 は高さ約2.6mの尖頭形筒状ヴォールトで稪われている。2 階において低い尖頭形アーチの連続する柱廊が中庭 3 辺を めぐるが、北辺は入口通廊によって途切れ、完全に一周し ていない。1階とほぼ同じ位置に配された計27の房室はい ずれも筒状ヴォールトがかかっている。構造的には 1 階の 八角形ピアは 2 階までのび(断面は四角形となる)、アーチ で連結されている。この中庭側ファサードが表わすように、 機能的にも 1 ・2階は一体で業務用として使用されていた ものと推定される。このことは 3 階から上階へのアクセス が別の戸口・階段により街路から直接行われていたことか らもわかる（現在は中庭北東隅の階段が使われる）。

いずれも時の最高権力者が創建した建築物として、規模、 構成、意匠などあらゆる点で代表的な作品である。1、2 階諸室の扱いに相違がみられるものの、クトゥン（No. 33） やザラーキシュ(44)を含め、ほぼ共通した入口ボータルの 意匠にその時代性が最もよく表れている。

【3-2 オスマン朝支配前期の実例】16〜17世紀の属する 遺構は24例を数えるが(表-2)、そのうち16世紀のものは夕 グリーバルディー（No. 27)以外はすべてブーラーク地区に 所在する。㛐瓦造の円形ピアがたつシナーニーヤ(70)を除 き、それら16世紀ブーラーク地区のものは概して數地面積 が大きく、その多くが 1 階に柱廊をめぐらす構成をとる。 前述のグーリー（45)の柱鄉とは異なり、幅員が広くとられ、 アーチは 1 階で完結している。上階も設けられたが、高層 な建物ではなかったらし( ${ }^{16)}$ 。人口通廊の高さは 1 階の階 高内に押さえられ、入口ポータルも低く、三葉形に代わっ て弓形ヴォールトとなっている。 
1617/18年建設のナカーディー17)（No. 16）は東端のサビ 一ルを除き、面積700 $\mathrm{m}^{2}$ あまりで現存遺構の中では中規模程 度である(図-5)。間口 $3.8 \mathrm{~m}$ ・奥行 $1.4 \mathrm{~m}$ の入口ボータルは 高さ約 $4.8 \mathrm{~m}$ の浅い弓形ヴォールトがかかり、外壁上部には 石造持送りがつき、 $1.5 \mathrm{~m}$ ほどの張り出しを受けていた。弓 形アーチがかかる扉口上部には六角形の結び目を持った紐 状の装飾帯が施され、アーチ起栱部にはムカルナス状の柱 頭らしき装飾がついている。奥行 $6.9 \mathrm{~m}$ の入口通廊には 2 つの交差ら゙ォールトがかかっている（図-3/18）。一部改装 されているが、およそ東西 $15 \mathrm{~m}$ ・南北 $13 \mathrm{~m}$ の中庭に面して現 在計 13 の房室が配され、概ね2.7〜 $3.0 \mathrm{~m}$ の間口に高さ $4.1 \mathrm{~m}$ の石造筒状ヴォールトがかかり、その前には奥行 $1.2 \sim 1.5$ $\mathrm{m}$ のアルコーブが備わる ${ }^{18}$ (図-4)。なお、南東隅部分には 階段が備わるが、上階はほとんど現存していない。

ザハビー(No. 28) は創建者の住宅(文化財No. 72) と同じ 1637/38年の建設と考えられてきたが ${ }^{19) 、 そ れ よ り も 2 〜 ~}$ 5 年早い時期の建設とする説もある ${ }^{20)}$ 。南東隅部に付属す

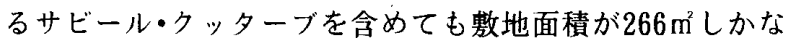
い小規模なワカーラである(図-6/13/14)。間口 $3.4 \mathrm{~m}$ に弓形 アーチのかかる入口ポータルの奥行は極めて浅いが $(0.5 \mathrm{~m}) 、$ その高さは $5 \mathrm{~m}$ ほどで他に少らない（図-22）。弓形アーチ の翡口、アーチ周囲の結び目付き紐状装飾帯、アーチ迫り 元の 3 段のムカルナス装飾なども前例とほぼ同様である。 人口通榔は浅い筒状ヴォールトと、その奥に交差ヴォール 卜を組み合わせている。南北 $6.3 \mathrm{~m}$ ・東西 $8.3 \mathrm{~m}$ の中庭に面 して、南北辺に計 5 つの房室が 1 階に配されるのみである。 これら 5 室はいずれも尖頭形ヴォールトで覆われ、当初は どれにもごく浅いアルコーブが備わっていた。アルコーブ が浅いため、1階壁面上部には石材の持送りが各所につき、 上階の無蓋の回廊(テラス)を支えている(図-13/14)。テラ スに面して配された 2 階房室は 1 階同様、ヴォールト天井 がかかり、尖頭アーチ形の扉口もいくつか遺されている。

表-2 オスマン朝前期の現存ワカーラ（1518年〜17世紀末）

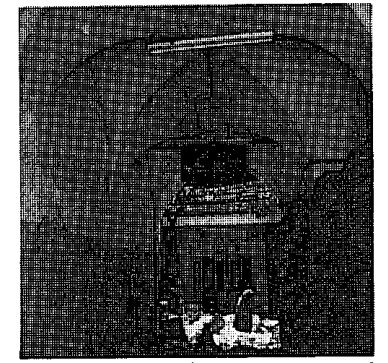

図-3 ナカーディー/入口通廊

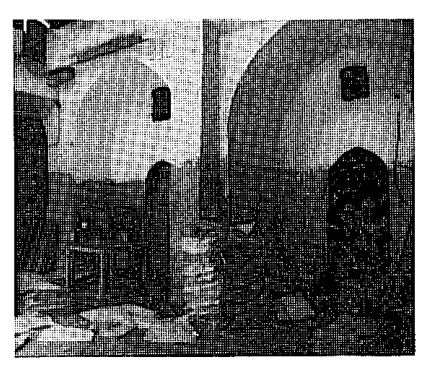

図-4 同/房室・アルコーブ

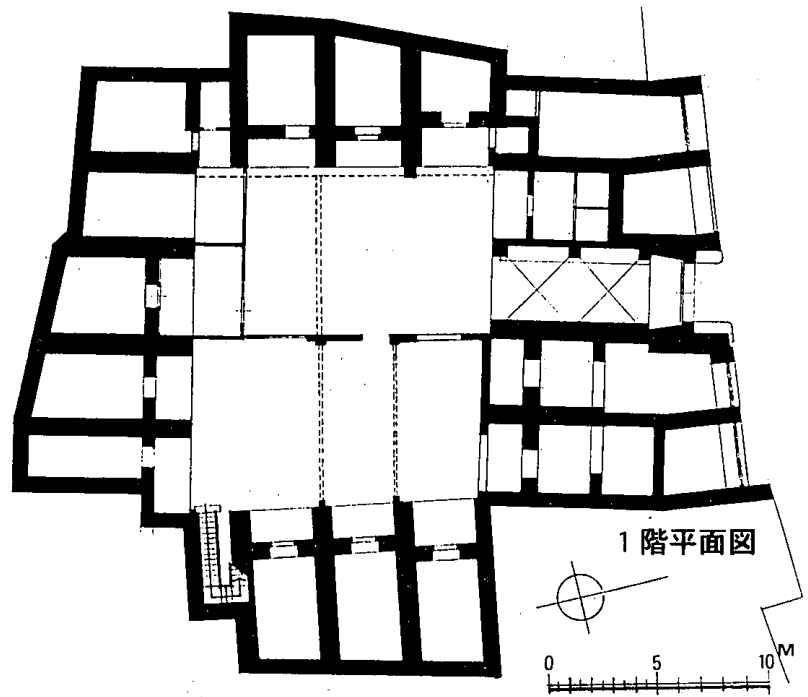

図-5 ナカーディー(No.16)

（1994年8月/9月/12月案䐓期查）

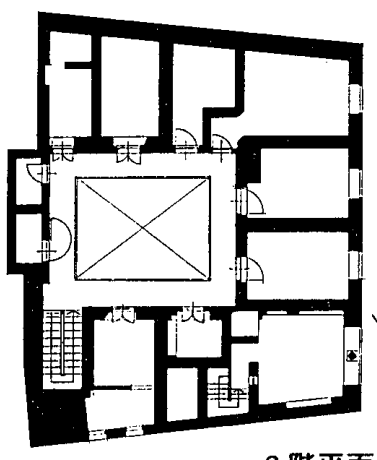

図-6 ザハビー(No. 28)

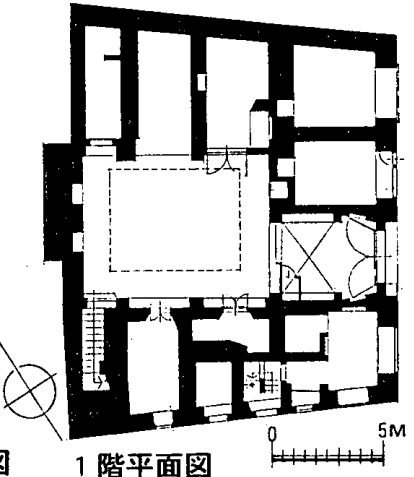

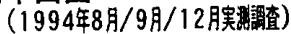

\begin{tabular}{|c|c|c|c|c|c|c|c|c|c|c|c|c|c|c|c|c|c|c|c|c|c|c|}
\hline No. & 名标(速貶玵) & $\begin{array}{r}\text { 政地面约 } \\
\mathrm{m}^{2}\end{array}$ & $\begin{array}{c}+4 \mathrm{~m}^{2} \\
\mathrm{~m}^{2}(\mathrm{x})\end{array}$ & $\begin{array}{c}\text { 屏 } \\
\text { 数数 }\end{array}$ & 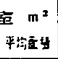 & 形状 & $\begin{array}{l}\text { Tル } \\
\text { 用口 }\end{array}$ & ーフ m & 高 & 众 & 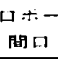 & タル" & 海 & 形状 & 只 & & 天烡 & $\begin{array}{l}\text { 口通 } \\
\text { 淂口 }\end{array}$ & 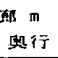 & 位帮 & 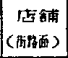 & $\begin{array}{c}+2 \pi-4 \\
40\end{array}$ \\
\hline 61 & Sukariya(1541/2) & 1800 & $342(19)$ & - & - & - & - & - & - & 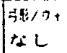 & 3. 3 & 1.2 & 3.5 & $\begin{array}{l}\text { 改留 } \\
\text { 水平 }\end{array}$ & $-\overline{2 .}$ & 2. 9 & 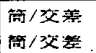 & $\begin{array}{l}3.0 \\
3.5\end{array}$ & $\begin{array}{r}9.0 \\
11.0\end{array}$ & $\begin{array}{l}\text { 中央 } \\
\text { 中央 }\end{array}$ & $\begin{array}{l}6 \\
0\end{array}$ & $\begin{array}{l}x \\
\times\end{array}$ \\
\hline 68 & Kharnab(b. 1571) & 3540 & $955(27)$ & 40 & 39 & $i \neq$ & E鄵：幅 3 & 3. $0 \mathrm{~m})$ & & 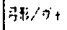 & 4. 3 & 1.1 & 3. 4 & 弓形 & 3. 0 & 2. 8 & 筒/被2 & 3. 9 & 13. 6 & 中央 & 6 & $x$ \\
\hline 58 & Hesan Pasha(1583) & 8376 & $2550\langle 30\rangle$ & $(58)$ & (48) & $c t$ & 主䂙：幅 5 & 5. $0 \mathrm{~m}$, & & 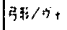 & 3. 6 & 1.3 & 5. 2 & 弓形 & 2. 6 & 3. 8 & 简/交到 & 4. 5 & 18. 0 & 中央 & - & - \\
\hline 27 & TaghrI Bardi(16c.) & 446 & - & - & - & - & - & - & - & $\$ L$ & & & & 水平 & 2.1 & 2.7 & 筒/交烡 2 & 2. 4 & 9.5 & 陪 & 0 & $\times$ \\
\hline 62 & Dhahab(16c.) & 1316 & - & (-EDDR & & $<*$ & (t.tis & & & 改蔆 & - & - & - & 改贸 & - & - & 陑伩盖 & 3. 0 & 10.5 & 中央 & 4 & $x$ \\
\hline 63 & Zayt(16c.) & 3360 & $693(21)$ & 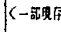 & & 尖頭 & - & - & - & 破担 & - & - & - & 破提 & - & - & 破損 & - & - & $\Delta$ & 7 & $x$ \\
\hline 68 & Rab Sinantya(16c.) & 929 & - & - & - & - & - & - & - & $3 * 0 \% 7$ & 3. 5 & 1. 5 & - & 㞋形 & 2. 5 & - & 勿/交养 & 3. 2 & 10.0 & 中央 & 4 & 0 \\
\hline 70 & Sinaniya(16c.) & 656 & $116(18)$ & 2 & 47 & 挂恝 & 2. $8-4.1$ & 0.9 & - & $12 L$ & & & & 户形 & 2. 5 & 3. 2 & 简形 & 3. 9 & 9.6 & 中央 & 4 & $x$ \\
\hline 59 & Sarban(16 17c.) & 1424 & $234(16)$ & (24) & (37) & $(* 1)$ & E酣：幅 3 & 3. $2 \mathrm{~m})$ & & $5.6 / 7+$ & 3. 3 & 1.5 & 4.8 & 宁形 & 2.4 & 3.4 & 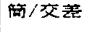 & 3. 0 & 7.0 & 如央 & 11 & $\times$ \\
\hline 16 & Naqadi $(1617 / 8)$ & 702 & $199(28)$ & 13 & 17 & 父顽 & 2. $7-3.5$ & 1. $4 \sim 2.0$ & 4. 1 & 3.5: $/ 7+$ & 3. 8 & 1.1 & 4.8 & 弓形 & 2.7 & 3. 9 & 放/ 12 & 2. 9 & 8. 6 & $\Delta$ & 1 & 0 \\
\hline 28 & Dhahabic16 & 6 & a) & 5 & 15 & 尖顽 & 2. $6-2.7$ & 0.5 & 3. 6 & 5*/7 & 3. 4 & 0.5 . & 5.3 & ら形 & 2.3 & 4.5 & 份公差 & 3. 1 & 4. 5 & $\triangle$ & 3 & 0 \\
\hline 20 & Sawt $($ mid. 17 & 333 & $65(20)$ & 7 & 21 & 尖頭 & 2. $6-3.0$ & 0.8 & 2.7 & कास $/ 7+$ & 3. 4 & $0.6^{\circ}$ & 3. 4 & 马形 & 2. 3 & 2.7 & 筒/父整 & 2.5 & 3.2 & 中央 & 4 & $x$ \\
\hline 50 & Radwan $\operatorname{Bey}(c .1650)$ & $4280 ?$ & $1780(42)$ & - & - & - & - & - & - & なL? & - & - & - & 马形 & - & -- & 棈/父萃 & - & - & 踝? & 37 & $\times$ \\
\hline 9 & Oda BashI(1673) & 1474 & - & - & - & - & - & - & - & Fathot & - & - & - & 形 & - & - & 筒/交荎 & - & - & $\triangle ?$ & $\mathbf{9}$ & 0 \\
\hline 13 & Dho' I-Fiqars(1673) & 3066 & $1196(39)$ & 32 & 50 & 炙㫜 & 3. $4-4.1$ & 1. $5 \sim 2.5$ & 4. 0 & ink $17+$ & 4. 2 & 1.2 & 3.8 & 宁形 & 2.7 & 2.5 & 简/知 2 & 3. 4 & 12.8 & 陪 & 11 & $x$ \\
\hline 15 & - Abbas $\operatorname{Agha}(1694 / 5)$ & 1452 & - & - & - & - & - & - & - & 张 $/ \cdots+$ & 4. 2 & 0.8 & 4. 5 & 弓形 & 2. 7 & 3.5 & - & - & - & - & - & - \\
\hline 67 & Shawam $(16 \sim 17 c)$. & 1870 & - & - & - & -- & - & - & - & 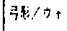 & 3. 3 & 1.0 & - & 弓形 & 2.3 & 2.8 & 第/交美 & 3. 3 & - & $\Delta ?$ & $17 ?$ & $x$ \\
\hline 26 & Katkhuda (17c.) & 610 & $143(23)$ & - & - & 头呾 & - & - & - & इ\$: & 3. 5 & 1.0 & - & 弓形 & 2.8 & - & 筒/交焉 & 3. 0 & 9. 0 & 中央 & 5 & $x$ \\
\hline 43 & Mat & 49 & - & - & -- & - & - & - & - & 改装 & - & - & - & 改装 & - & - & 鈛 & - & - & 中央? & $4 ?$ & $\times$ \\
\hline 14 & Bazar a (end 17c.) & 1275 & $324(25)$ & 25 & 34 & 円的 & 2. $3-3.6$ & 1. $5-2.3$ & 3. 2 & $F_{13} / \mathrm{m}$; & 4. 6 & 0.7 & 6. 2 & 与形 & 3. 3 & 3.4 & 荫/交差 & 3. 2 & 7. 9 & 中央 & 7 & $x$ \\
\hline 7 & Murgan(end 17c.) & 925 & 6) & - & - & - & - & - & - & 张 $\Rightarrow$ & - & - & - & ק形 & - & - & - & - & - & 踝? & $2 ?$ & $x$ \\
\hline 10 & Shishini (end $17 \mathrm{c}$.) & 626 & $226(36)$. & 16 & 17 & 坐的而 & 2. $5-3.1$ & $0.7-1.7$ & 4. 2 & 强/ & 3. 6 & 0.7 & 4. 7 & 弓形 & 2. 3 & 3.0 & 简/父瑟 & 3. 0 & 7.1 & 行央 & 0 & $x$ \\
\hline 66 & ' Asli(end 17c.) & 1155 & - & - & - & ( 淁 & 㨽㸝一一 & 一千昰のみ & क) & 砧 & - & - & - & 破臫 & - & - & 破椇 & - & - & - & - & - \\
\hline 72 & Mirza(c. 1698) & - & - & - & - & - & - & - & - & 破提 & - & - & - & 破㨡 & - & - & 破損 & - & - & - & $=$ & - \\
\hline
\end{tabular}


聞き取りによると西側部分に 3 階への階段であったという が、3階部分はまったく現存しない。現状で各室は工房と して使われているが、当初から 2 階は業務用として使用さ れたと考えられる211。

この時期においては、サーウィー(No. 20)やシーシーニー (10)など小・中規模のものが建設されていることに留意す ベきであろう。一方、17世紀後期にはオーダ・バーシー(9)、 ズール・フィカール(13)、アッバース・アーガー(15)、バー ザルア(14)など大規模なワカーラがお互い近接した位置に 建設されたことも注目される。しかも、いずれも筒状ヴォ ールトのアルコーブ付き房室、弓形の入口ポータルや扉口、 入口上部の張り出しなどょく似た意匠・構成である。

【3-3才スマン朝支配後期の実例】18世紀までに属する 13例に加えて、年代不詳ではあるが、おそらく少なくとも 5 例はこの時代に含まれよう（表-3）。

入口の木製門扉にのこる彫刻の碑文により、アブー・アッ ルース ${ }^{22}$ (No. 30) の建設は1718/19年とされる。商業的中 心地に立地するため、1 階部分は改修が多く、把握しにく い。入口ポータルは弓形ではなく半円アーチで、下端に細 かなモールディングが付くが、扉口には依然浅い弓形ア一 チがかかる。人口通廊は例によって交差と筒形のヴォール 卜構成であるが、交差部が $1.5 \mathrm{~m}$ ぼと狭くなっている。 2 階は中庭に面して $650 \times 1,130 \mathrm{~mm}$ のピアが規則的に立ち、 半円形にごく近いアーチで結ばれている（図-7）。中庭を めぐる幅員 $1 \mathrm{~m}$ の回廊にも、ピアと各室の壁との間を低く 浅い弓形アーチが結んでいる。これに面する計23の房室は 半円アーチ状の扉口を備え、高さ $3 \mathrm{~m}$ ほどの筒形ヴォール トがかかる。2階はす心゙て工房として使用されている。

シャラーイビー(No. 48)は創建者の死亡年(1725)から、18 世紀はじめ、おそらく1710～20年代の建設とされる ${ }^{23) 。 ア ~}$ ルコーブ付き房室が並ぶ標準的平面をした中規模のワカー ラである(図-9)。人口上部は現在大きく破損しているが、 出空であったと推定される巨大な張り出しが設けられてい た。入口ポータルは 2 層分ほどの高さに弓形アーチがかか り、高さに比して奥行は $1 \mathrm{~m}$ なく浅いが、上部の大きな 張り出しはその代わりであるかもしれない(図-8)。屝口上

表-3 オスマン朝後期の現存ワカーラ（18世紀～1805年）

方の壁面の結び目付きの紐状装飾帯やアーチ起栱点下部の ムカルナス状装飾などはこれまでもみられたが、アーチの エクストラドスに施された波形の文様や壁面上方の 4 つの 12弁形メダイオンは目新しい。

セルガーニー(No. 22)、キルダーニー（23）、ムハンマダ イン (24)の 3 例はいずれも近隣に所在し、規模や構成に類 似点が多い。特に後 2 者は互いに道を挟んで向かい合い、 呼応するように門を開いている。また18世紀末の大規模ワ カーラ、ナフィーサ(49)の入口ポータルは主要街路沿いに 立地することもあって、極めて印象的な意匠がみられる。

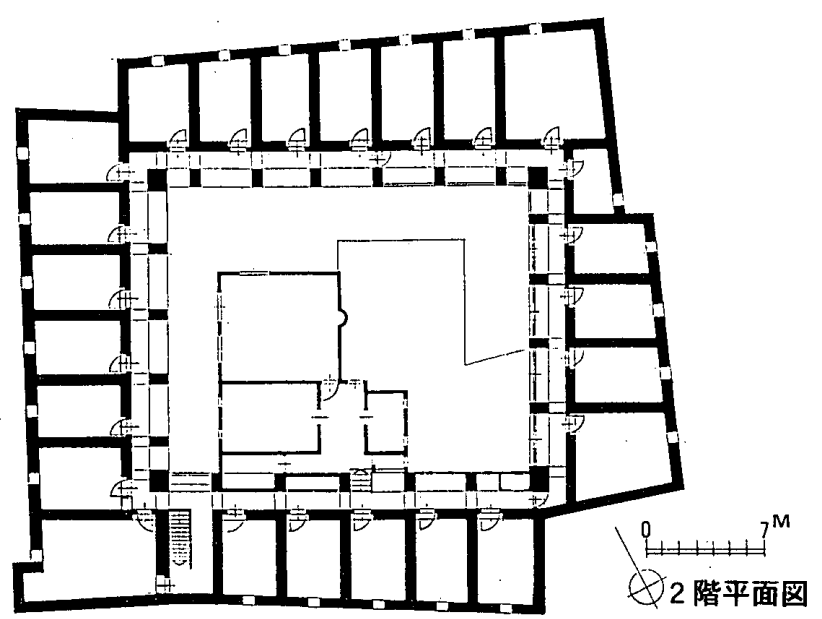

図-7 アブー・アッルース(№. 30)

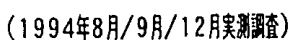

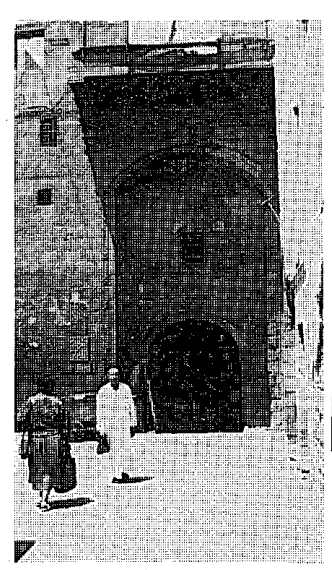

図-8 シャラーイビー(№.48) /入ロポータル

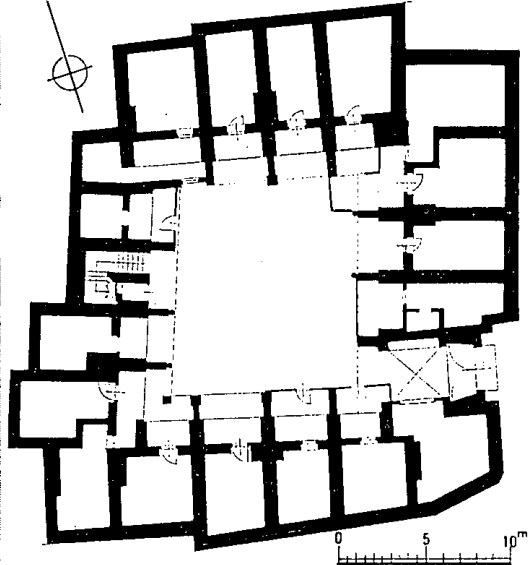

図-9 同/ 1 階平面图

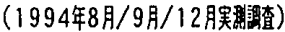

\begin{tabular}{|c|c|c|c|c|c|c|c|c|c|c|c|c|c|c|c|c|c|c|c|c|c|c|}
\hline \multirow[t]{2}{*}{ No. } & \multirow[t]{2}{*}{ 公称(建炈年) } & \multirow{2}{*}{$\begin{array}{r}\text { 晋地丽得 } \\
\mathrm{m}^{2} \\
\end{array}$} & \multirow{2}{*}{ 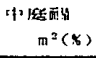 } & \multicolumn{2}{|c|}{ 焉 $\mathrm{m}^{2}$} & \multicolumn{4}{|c|}{ ナルコーブ m } & \multicolumn{4}{|c|}{ 人口ホータル $\mathrm{m}$} & \multicolumn{3}{|c|}{ 的口m } & \multicolumn{4}{|c|}{ 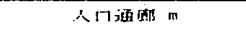 } & \multirow{2}{*}{ 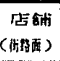 } & \multirow{2}{*}{$\begin{array}{l}4 \leq-4 \\
40\end{array}$} \\
\hline & & & & 案数 & 平均西年 & 形状 & 问品 & 䓡行 & 南 & 形状 & 間口 & 和 & 深 & 形状 & 幅 & 两 & 天井 & דו & 尖行 & 位垪 & & \\
\hline 60 & Ganblat (17 18c.) & 1383 & - & - & - & FL & & & & $12 L$ & & & & 户形 & 2.9 & 2.1 & 成分交 & 4.0 & 11.0 & 阱? & - & - \\
\hline 64 & Dukhan (17 -18c.) & 816 & $256(31)$ & 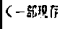 & & 尖䚴 & 3.1 & 1.5 & 1. 5 & 做㛘 & - & - & - & 改装 & - & - & 筒/父莘 & 3. 8 & 6. 0 & 隅 & 0 & $\times$ \\
\hline 65 & Magharba( $17 \sim 18 c$. $)$ & 263 & - & -. & - & - & - & - & - & 改装 & - & - & - & 故装 & - & -- & - & - & - & 隄? & 4 & $x$ \\
\hline 71 & Khashab $(17-18 c)$. & 400 & - & - & -- & - & - & - & - & 改装 & - & - & - & 改装 & - & - & 筒/交导 & - & - & 陆 & 4 & $\times$ \\
\hline 73 & Zardakash $(17 \sim 18 \mathrm{c})$. & 519 & - & - & - & -- & - & - & - & 改裴 & - & - & - & 改㠇 & - & - & 简/交至 & - & - & - & 3 ? & $x$ \\
\hline 30 & Abo ar-Ras $(1718 / 9)$ & 1192 & $357(30)$ & 23 & 34 & 问䤄 & - & - & - & *\#/月。 & 3. 9 & 1.0 & - & г形 & 2.5 & - & 简交/交落 & 2. 8 & 7. 6 & 陆 & 5 & $\times$ \\
\hline 48 & Shara ibl (ear. $18 \mathrm{c}$.) & 738 & $126(17)$ & 18 & 31 & 父䭪 & 2. $3-3.4$ & 1. 5 & 3. 6 & $3 t / 2+$ & 3. 8 & 0.8 & 7. 9 & 弓形 & 2.5 & 3. 3 & 间次等 & 3. 0 & 5.5 & 䧑 & 0 & $\times$ \\
\hline 22 & Sergant (18c.) & 852 & $233(24)$ & 19 & 28 & 㳇昜 & 2. $6 \sim 3.0$ & 1. $3-1.5$ & 4. 8 & 破损 & - & 0.7 & - & 兮形 & 2.4 & 2. 9 & 筒/交羔 & 2. 8 & 7. 2 & 隅 & 0 & $\times$ \\
\hline 23 & Kirdani(18c.) & 1324 & $298(23)$ & 19 & 28 & FL & & & & 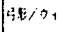 & 4. 0 & 1.1 & 5.3 & 马形 & 2.7 & 3.5 & 第/交蓄 & 3. 0 & 7.3 & 佒 & 7 & 0 \\
\hline 24 & Muhammada in (18c. ) & 1037 & $398(38)$ & 19 & 22 & 爸明 & 2. $9-3.1$ & $1.5-1.6$ & - & $30 / m+$ & 1. 0 & 1.1 & 4. 9 & 弓形 & 2. 8 & 3.1 & 间佾童 & 2. 9 & 7.8 & 中央 & 7 & $\times$ \\
\hline 42 & Sanadalya(18c.) & 612 & $75(12)$ & - & - & $12 L C$ & 造口， & & & 改装 & - & - & - & 改装 & - & - & 成/站 2 & 2. 8 & 11.0 & $E A$ & 3 & $\times$ \\
\hline 31 & Shahin (18c.) & 453 & - & - & - & - & - & - & - & 改技 & - & - & - & 改索 & - & - & - & - & _- & - & - & $x$ \\
\hline 49 & $\operatorname{Naf} 1 \mathrm{sa}(1.796)$ & 2288 & $683(30)$ & 32 & 11 & 㭅豉 & 3. 0 & 1.5 & - & 判 $1=$ & 3. 9 & 1. 6 & 5.7 & 及形 & 2. 6 & 2.8 & 成份交苇 & 3. 2 & 8. 8 & 中央 & 7 & 0 \\
\hline 3 & Amtr al-Guyosh & 304 & - & - & - & - & - & - & - & 强, & 3. 0 & 1.5 & - & 局形 & 2. 0 & - & - & - & - & - & 2 & 0 \\
\hline 4 & Ganain 1 & 1155 & $322(28)$ & - & - & なしC & 持送り) & & & 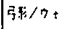 & 3. 0 & 1.3 & 3. 6 & 马形 & - & - & 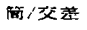 & 3. 0 & 10.0 & 㠶 & 6 & $\times$ \\
\hline 18 & Kharaba & 620 & - & - & - & 父达頭 & - & - & - & なL & & & & 乃形 & 3.5 & - & - & - & - & 陆? & 4 & $x$ \\
\hline 21 & $\mathrm{Se}^{\prime} \mathrm{id}$ & - & - & - & - & な LC & 持送り) & & & な & & & & 弓形 & 2. 2 & 2.2 & 筒/罂 2 & 2. 8 & 12.0 & 唡 & $\mathbf{0}$ & $\times$ \\
\hline 51 & Khairi & 868 & $140(16)$ & - & - & 尖致 & - & - & - & इस/को & 4. 0 & 0.3 & 3. 8 & ら形 & 2.3 & 2.8 & 筒/交䓺 & 1. 3 & 7. 0 & 中共? & 1 & $\times$ \\
\hline
\end{tabular}


すなわち、伝統的な結び目つき紐状装飾帯に加え、約 $2.6 \mathrm{~m}$ 幅の㗺口にかかる弓形アーチ下端の細かなモールディング、 その上部 3 段ほどのムカルナス、そこから直線的に斜め上 方に迫り出されたテュンバノン、さらに半円アーチ状の 2 重モールディングなど、これまでにない装飾が目につく。 また入口上部に大きく張り出した木製出空は、完全な姿で 残されている実例が少なく、特に注目される。

【3-4 近代期の実例】19世紀以降のムハンマド・アリー 朝などに属するものとして、年代不詳のものが多く含まれ るが、22例とした（表-4）。

いわゆるハーン・アルハーリーリー地区内に所在するシ ラーフダール 24) (No. 34)の入口ポータルは極めて技巧的な

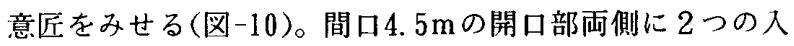
り隅をつくり、そこに2本の円柱をたて、多重モールディ ングの施された半円アーチでそれらを結んでいる。最外周 のモールディングはジグザグの縁飾(シェヴロン)となって いる。その下のテュンパノンには、両側に紋章のような模 様をおき、長方形に枠取りされた碑文が揭げられている。 碑文のなかに記されたAH1235(AD1837)の年号が建設年とさ れる。2 組の円柱は柱頭やアバックス、シャフトなどそれ ぞれデザィンが異なる。浅い弓形の扉口の下端にも同様の シェヴロンが施されている。アーチ迫り元に柱頭飾りらし きものは付くが、ムカルナス状をしていない。シュブロン などの濃密なモールディング、円柱のつけ柱などが、これ までのムカルナスや紐状装飾帯などに取って代わっている。 このような意匠は、ホーシュ・ウターイ(No. 12)にも共通し ている。入口通廊はヴォールトではなく、高さ $4.55 \mathrm{~m}$ の木 製天井で覆われている(図-19)。ただし、中庭に直接面する 部分には、石造の半円アーチがかかる。

わずかに当初の姿を残す 1 階中庭北辺と東刀の一部から すると、ほぼ同形の房室が規則的に配列されていたらしい (図-12/16)。すなわち 1 階各室は間口 $2.55 \mathrm{~m}$ に高さ $3.81 \mathrm{~m}$ の半円形筒状の石造ヴォールトで覆われ、その前面 $1 \mathrm{~m} に$ はアルコーブ部分が付く。西側街路に面した別の入口から

\section{表-4 近代期の現存ワカーラ（19世紀以降）}
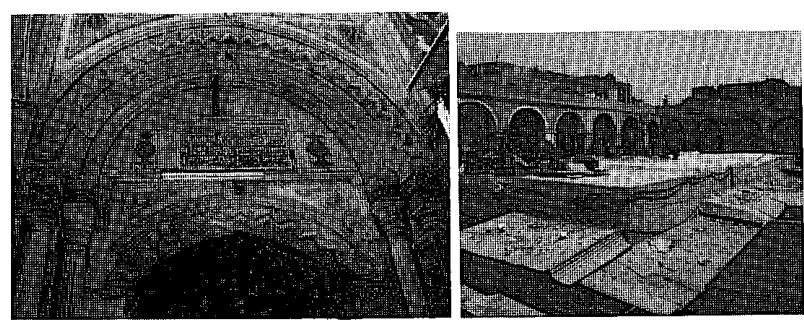

図-10 シラーフダール/入ロポータル 図-11 同/ 2 階中庭
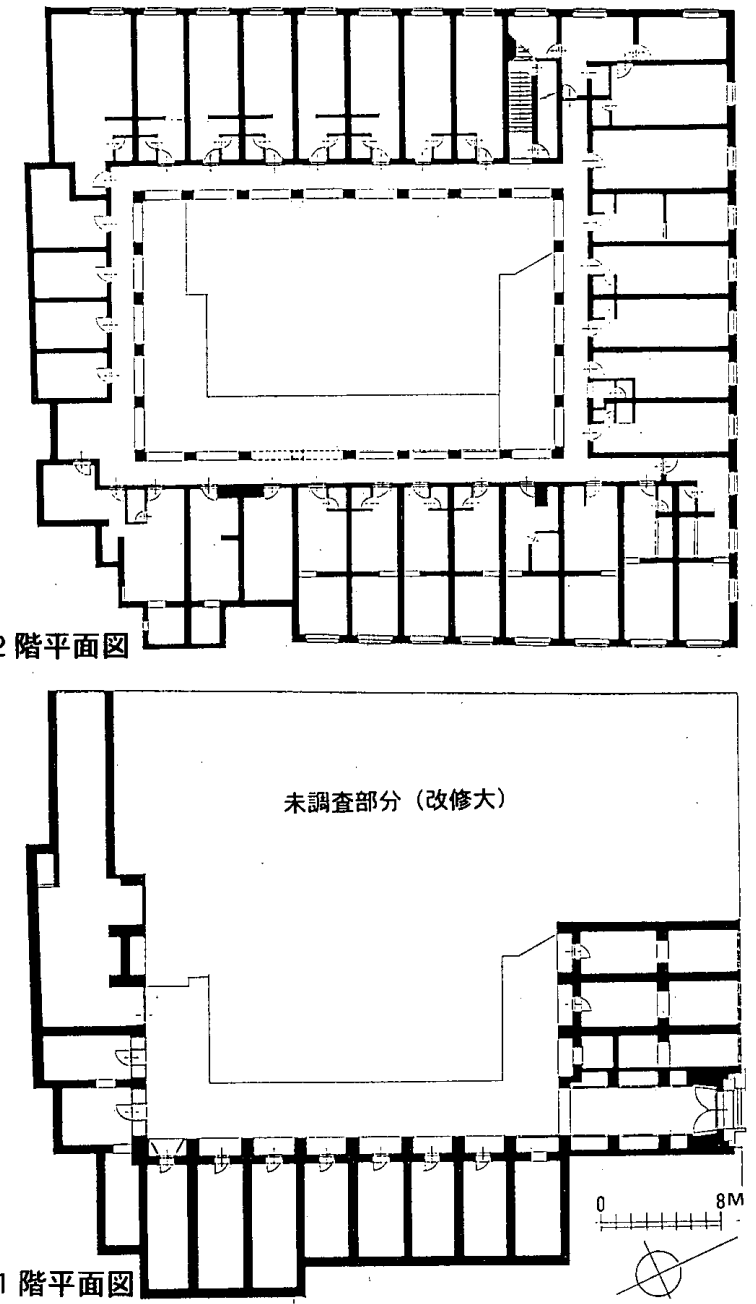

図-12 シラーフダール(№.34)

（1994年8月/9月/12月实期查）

\begin{tabular}{|c|c|c|c|c|c|c|c|c|c|c|c|c|c|c|c|c|c|c|c|c|c|c|}
\hline No. & 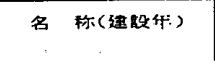 & 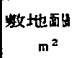 & $\begin{array}{c}\text { 中盾䣱圆 } \\
\mathrm{m}^{2}(\mathrm{x})\end{array}$ & $\begin{array}{l}\text { 仿 } \\
\text { 空数 }\end{array}$ & 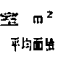 & 形状 & $\begin{array}{l}\text { 丁ルコ一- } \\
\text { 閒口 }\end{array}$ & $\begin{array}{l}\text { ーブ m } \\
\text { 紫行 }\end{array}$ & 漓 & 人 & 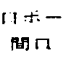 & 只打。 & 解 & 形状 & 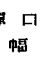 & $\mathrm{m}$ & 天乫 & 钥口通 & 磈 $\mathrm{m}$ & 安浑 & 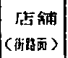 & 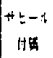 \\
\hline 12 & Hosh $\cdot$ tay $(1817 / 8)$ & - & - & - & - & 尖顽 & - & - & - & $\neq F / 2$ & - & - & - & 马形 & - & - & - & - & - & - & - & - \\
\hline 34 & Stlabdar (1837) & 1752 & $416(24)$ & 28 & 29 & 冈頭 2 & 2. $5 \sim 2.6$ & 1.0 & 3. 8 & 半闻/ & 4. 5 & 0.6 & 6. 5 & 户形 & 2.4 & 3.8 & 木製䧇 & 3. 1 & 10. 1 & m & 27 & $\times$ \\
\hline 32 & Haramain $(1855 / 6)$ & 1385 & $448(32)$ & 23 & 37 & 尖頭 1 & $1.8-3.0$ & $0.9 \sim 2.3$ & 3. 8 & 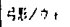 & 3. 8 & 1.1 & 3.8 & 吕形 & 2.5 & 3. 2 & 第/交蒕 & 3. 0 & 6. 1 & $\Delta$ & 4 & 0 \\
\hline 18 & $\operatorname{sinanin}(18 c)$. & 785 & - & - & - & 尜䁚 & - & - & - & tol & & & & 半円 & 3.5 & - & 破抯 & - & - & 中央 & 12 & $x$ \\
\hline 2 & Hasan Gum a & 268 & $62(23)$ & 9 & 13 & なしく & 样型） & & & 半球 & 2. 4 & 0.9 & 4. 9 & 屉形 & 1.6 & 3.1 & 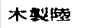 & 2. 0 & 3. 0 & $\Delta$ & 4 & x. \\
\hline 17 & Tuffab & 1572 & $244(16)$ & - & - & 美阴 & - & - & - & $\% \approx / \eta+$ & 3. 5 & 0.5 & - & 弓形 & 3. 3 & - & 木些除 & 3. 3 & 20.0 & $\Delta$ & 2 & $x$ \\
\hline 11 & Abo 2 Id & 356 & $60(17)$ & 7 & 20 & \&LC & 持送り) & & & $t=L$ & & & & 半円 & 2.1 & 3. 5 & 木陸/留 & 2. 2 & 11.1 & 中央 & 3 & 0 \\
\hline 47 & $\mathrm{Sa}^{\prime}$ id(ear. 20c.) & 1933 & $233(12)$ & 32 & 13 & TSL L & & & & ISL & & & & 特口 & 2. 2 & 4. 7 & 木㴶陻 & 3. 5 & 10.6 & 中央 & 43 & $x$ \\
\hline 1 & Shuwa $\mathrm{ikh}$ & - & - & $\ldots$ & - & - & - & - & - & FL & & & & 半且 & 2. 2 & 3.4 & 破損 & - & - & - & - & - \\
\hline 6 & Qamb & 384 & - & - & - & - & - & - & - & な & & & & 半円 & - & - & - & - & - & 靼? & $2 ?$ & $x$ \\
\hline 25 & Saghe al-Gadida & 348 & $57(16)$ & -- & - & \$2 & & & & なL & & & & 半円 & - & - & 改装 & - & - & 中央? & 2 & $x$ \\
\hline $2 \theta$ & Gawhargtya & 1715 & $484(29)$ & 23 & 49 & なし & & & & なし & & & & 半两可 & 2.4 & 4. 7 & 木紫陸 & 2. 9 & 9. 0 & 桧 & 0 & $x$ \\
\hline 36 & Zankalont & 877 & $150(17)$ & - & - & 小l & & & & なし & & & & 羊口 & - & - & 木製陸 & 3. 2 & 13. 5 & 中央 & 5 & $x$ \\
\hline 37 & za'abtt & 688 & - & - & - & - & - & - & - & な & & & & 埲口 & - & - & - & - & - & F & $18 ?$ & $x$ \\
\hline 39 & $Y a^{\prime} q a b$ & 1168 & $280(24)$ & - & - & $y_{2} L$ & & & & +2 & & & & 半门 & - & - & 木旼陸 & 3. 0 & 7. 5 & $\Delta$ & $38 ?$ & $x$ \\
\hline 41 & Qaffaş & 487 & $119(21)$ & - & - & $I=2$ & & & & 讨柱 & 4.5 & 0.8 & - & 半问 & - & - & 末柇陵 & 3. 5 & 11.0 & - & 4 & $x$ \\
\hline 52 & Umm al-Banat & 360 & - & - & - & - & - & - & - & $\neq \circledast 1 / 7$ & - & - & - & 智嗊 & - & - & - & - & - & - & 3 & $x$ \\
\hline 53 & Nahbas & 729 & - & - & - & - & - & - & - & 破㧩 & - & - & - & 弓形 & 3. 6 & 1. 0 & - & - & - & - & 8 & $x$ \\
\hline 54 & Mabmad & 565 & - & - & - & - & - & - & - & ISL & & & & 半际 & - & - & - & - & - & - & 5 & $\times$ \\
\hline 55 & Khalifa & 830 & $154(1 \theta)$ & - & - & - & - & - & - & ISL & & & & 半円 & - & - & - & - & -. & $\Delta ?$ & - & $x$ \\
\hline 58 & Dabab & 786 & $156(20)$ & - & - & TL & & & & ts L & & & & 半円 & 2. 3 & 4. 1 & - & - & - & 隅 & 6 & $x$ \\
\hline 57 & Qutn & 323 & - & - & - & - & - & - & - & $12 L$ & & & & 씃⿴囗十丁 & - & - & - & - & - & - & 4 & $\times$ \\
\hline
\end{tabular}


直接 2 階の柱廊にいたる。中庭四周に合計26本の煉瓦造ピ ア $(770 \times 570 \mathrm{~mm})$ をそれぞれ半円形アーチで結んでいる(図 11)。2 階各室は柱廊とともに、高さ $3.8 \mathrm{~m}$ の木造天井がか かり、南側の一部を除き、街路に空を持ち、戸口脇には便 所を備え、また室内が前後 $2 つ に$ 分割されているものが多 い。ワカーラとは別の入口・階段をもつことも含め、2 階 各室はもともと業務用ではなかった可能性が高い。

19世紀には八ラマイン(No. 32/図-15)のような保守的・懐 古的な例外はあるが、半网形のアーチやヴォールト、木造 天井などが一般的となる。さらに20世紀ともなると、サイ ード・バーシャー(47)やヤークーブ(39)など中心街路に面 してたつ大規模な独立建物が現れる。前者では 2 階空上部 のベジメントなど西欧の影響がみられる。平面は極めて規 則的で、1階の店舖・倉庫は四周の街路と通路のような細 長い中庭に面して背割りに、2階も中廊下を介しておそら く事務室(現在倉庫が多い)が配されている。東西南北それ ぞれのほぼ央に開く入口にはいずれも特別な意匠や装飾 はみられず、実用的な「ビル建築」となっている。

\section{4. 建築諸要素の歴史的变化}

【4-1 建物規模】カイロ最古とされるクースーン(No. 8) の數地は地籍図 ${ }^{25)}$ によると $3,600 \mathrm{~m}^{2}$ を超え、カイロ旧市街 内において、これに継ぐものにズール・フィカール(13)や クゥトン (33)があるが、概ね $1,000 \mathrm{~m}^{2}$ を超えるものを大規 模ワカーラとすることができよう。

現存例だけから言えば、マムルーム朝期のものはいずれ も $1,000 \mathrm{~m}^{2}$ 程度以上の規模を有している。また、オスマン 朝支配前期の 16 世紀、ブーラーク地区において集中的に建 設されたものは、ハサン・パーシャー(58)の約 $8,400 \mathrm{~m}^{2} を$ 筆頭にいずれもかなり大きい。このことは当時、ブーラー
クが商業新興地区として極めて重要であったことを示唆す るものである。一方、カイロ旧市街のオスマン朝期におけ る初出例タグリーバルディー $(27)$ が $500 \mathrm{~m}^{2}$ に満たない規模 であることが示すように、17世紀以降かなり小規模なもの がみらえる。ただ、大規模なものがその時々において建設 されていることも指摘できる。とくに17世紀後半のラドワ

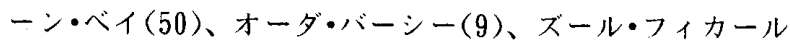
（13）、バーザルア (14)などは、カイロにおける商業交易活 動の推移をみる時、注目されるものであろう ${ }^{26) 。 ~}$

【4-2 房室配置】いずれのワカーラにおいても中庭に面 して房室が並ぶ。その大きさは15〜 $50 \mathrm{~m}^{2}$ の範囲にあるが、 20〜30 $\mathrm{m}^{2}$ のものが標準的と言える。奥行は敷地などによっ て異なるが、間口は $3 \mathrm{~m}$ 程度とほぼ一定している。一般に これら房室は尖頭形筒状ヴォールトがかかり、その前面に は同じヴォールトのアルコーブが備わる（図-4/13〜15）。 しかし、オスマン朝後期より円頭形のものが見られること (図-16)、グーリー(No. 45)や16世紀ブーラークのワカーラ においてアルコーブではなく、柱廊が採用されていること がこれにあてはまらない。

イスラーム建築のなかで中庭周囲にアルコーブを介して 小室を配する構成は、よく知られるように、イランや中央 アジアにおけるマドラサやキャラバンサライなどで中世以 来長く用いられてきた ${ }^{27)}$ 。力イロではマドラサやハーンカ 一などにもほとんどみられず28)、ワカーラに固有の建築形 式であるといえる。もっぱら実用本位の建築であるワカー ラに採用されているのであるから、やはり使用上に何かの 利便があるはずである。ズール・フィカールの中庭を描い た19世紀の絵をみると(図-17) ${ }^{29)} 、 1$ 階のアルコーブ前に は低い䒽が張られ、その上には木製の庇が差し榡けられて いる。アルコーブ周囲にはベンチやマシュラビーヤの衝立

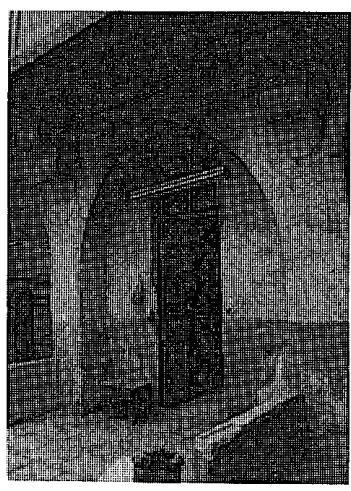

図-13 ザハビー 房室
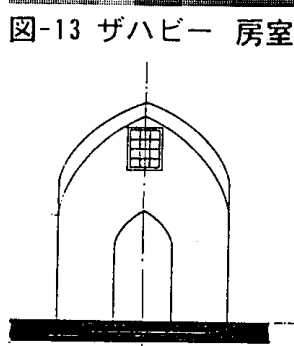

図-15 ハラマイン(No. 32)

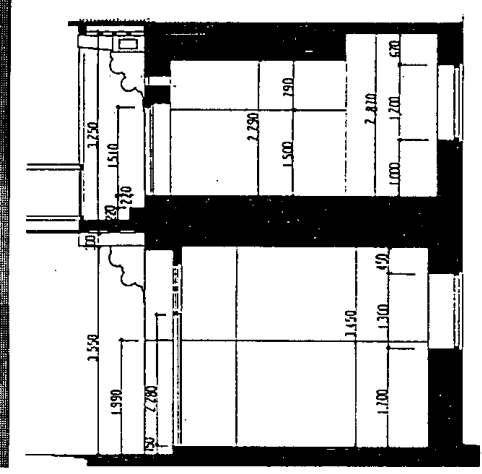

図-14 同/房室断面図

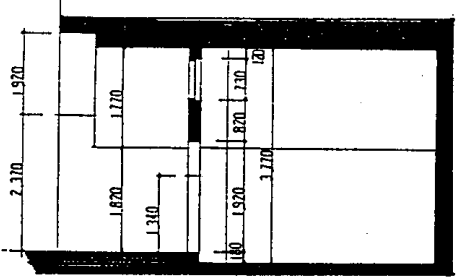

1 階房室立面図/断面図

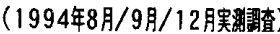

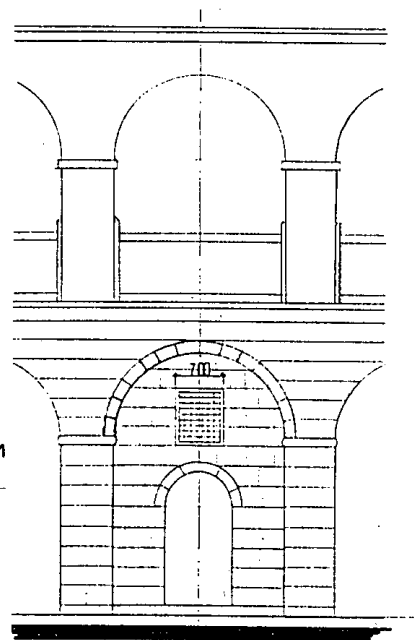

図-16 シラーフダール(No.34) 1 ・ 2 階房室立面図/断面图

（1994年8月/ 9 月/ 12 月实烌韧查） 
など㯰かれ、人ヶが商談している様子が見てとれる。つま り、ワカーラにおける1階アルコーブは主として店舗とし て積極的に使われたらしい。2階も業務用とする場合、グ ーリー(No. 45)、バーザルア(14)などのように、各室は中庭 周囲をめぐる柱廊に面して配され、上階に複合化されたう ブァ(集合住宅)とは異なる中庭意匠がみられる。ただし、 ザハビー(28)にみるように、小・中規模のワカーラではテ ラス状の回廊とされることもある(図-6/13/14)。

【4-3 入口通廊】ふつうワカーラは街路から中庭へ直線 的にアクセスできる幅員約 $3 \mathrm{~m}$ の通廊を有する ${ }^{30)}$ 。17世紀 までの実例では中庭を形成する 1 辺の中央に設けられるも のが多い(表-1/2)。マムルーク朝期のものはその高さが 6 $\mathrm{m}$ を超え、中庭に面して開く房室のアルコーブより一段と 大きく、明確にその位置が示されるが、2 階の平面、特に 回廊 (柱廊)に影響を与えている。一方、オスマン朝期の例 ではアルコーブとほぼ同程度の高さで、階高内におさまる ようになる。後述する人口ポータルの意匠とも対応するも ので、入口位置、建物への進入動線を中庭の中軸におき、 ある種のモニュメンタリティが表現されている。

前近代の事例ではおしなべて筒状と交差の尖頭形ヴォー ルトを組み合わせた構成がみられる。マムルーク朝期の例 では扉口直近より交差ヴォールトが用いられ、しかも単純 な四分ヴォールトではなく、8本の积線を描くものである。 オスマン朝期のものでは丞口のすぐ内側 $1.5 \mathrm{~m}$ ぼはほか の通廊部分より一段高くなった浅い弓形の筒状ヴォールト とし、四分交差部がそれに続く(図-18)。19世紀以降の近代 ワカーラでは、アーチ壁はみられるものの、もはやヴォー ルトとせず、木造天井となる(図-19)。

ファーティマ朝のナスル門(1087年)がおそらくカイロの 現存遺構における交差ヴォールトの初出例であろう。それ 以降の建築において交差ヴォールトはあまり一般的とは言 えないが ${ }^{31}$ 、建物入口に用いられた実例としてザーヒル・ バイバルスのモスク（1266-69年)が挙げられる。ハーキム・ モスク (990-1013年)の影響といわれる3箇所の突出した門 のうち、建物左右の門の外部側に交差ヴォールトが架かっ ている。ワカーラ入口通廊に普遍的にみる交差ヴォールト に直接つながる先例のひとつと考えられよう。

【4-4 入ロポータル】1階街路側には、グーリー(No. 45) など若干の例外を除き、中庭に面する房室とほぼ同じ間口 の小室が配されている。もちろんこれらは主に店舗として 使われ、同じ街路に立地する他の店舗と一体となって、連 続店舗群、いわゆるスークを形成している。

1 階店舗が隣接するものと融合しているのに対し、人口 だけは街路側ファサードにおいて際立って明快な形態・意 匠をもち、ワカーラ建築における最大の特徽となっている。 それはマムルーク朝期とオスマン朝期とではまったく異な るものであった。すなわち、マムルーク朝期においては三 葉形ヴォールトであり、オスマン朝期ではそれが弓形のヴォ
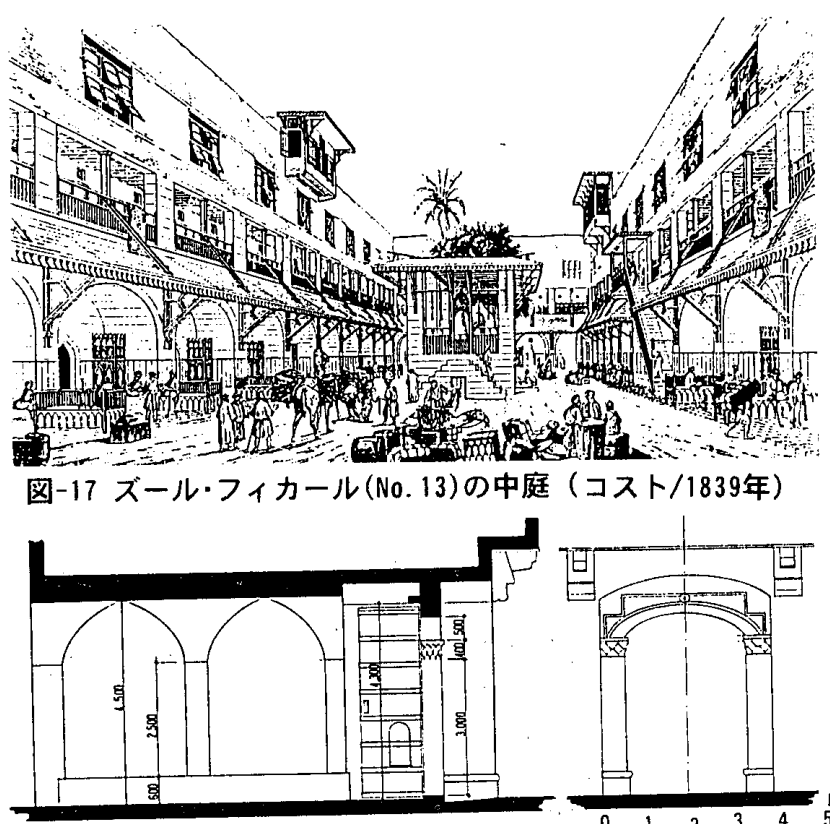

図-18ナカーディー 入口通廊断面図

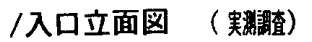
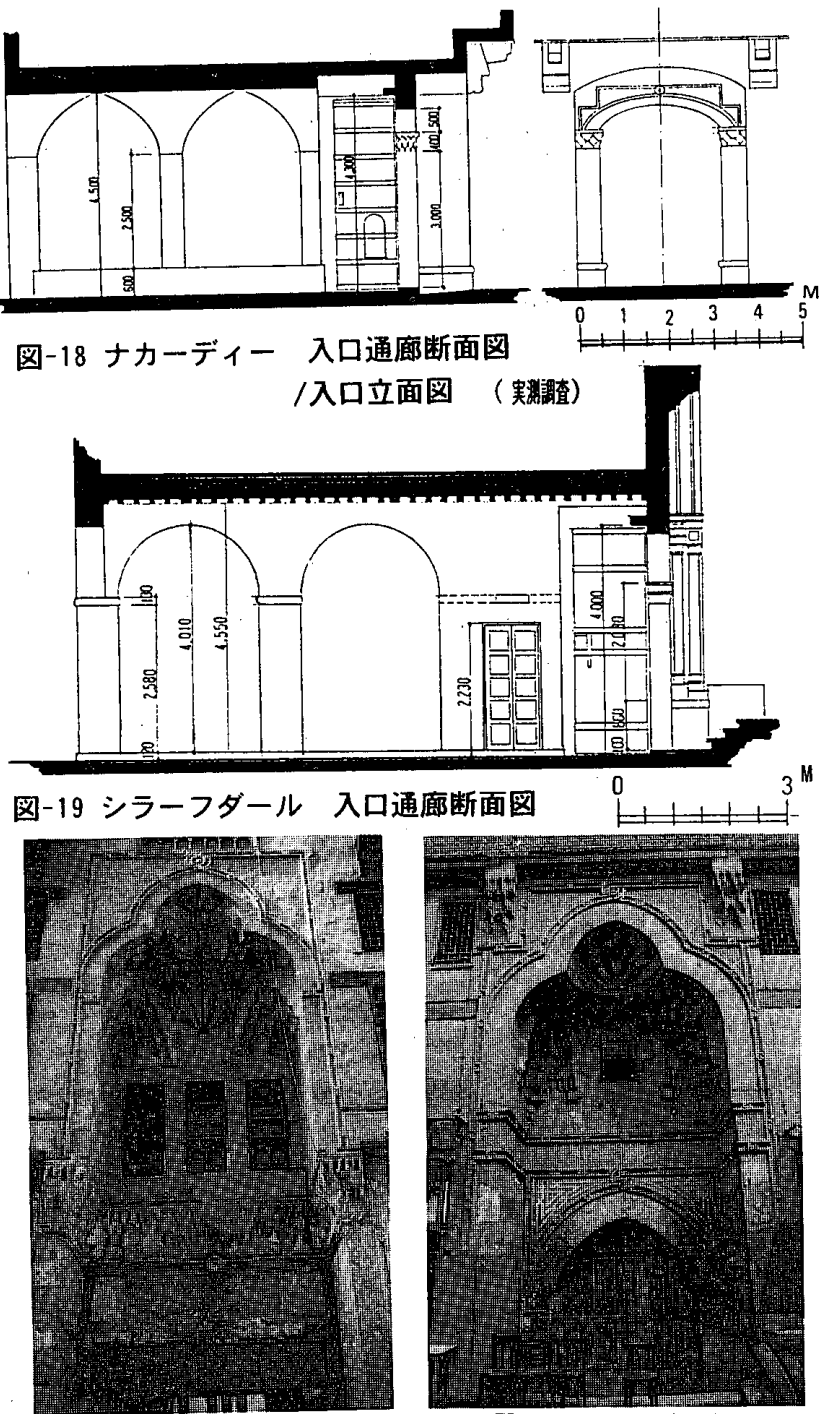

図-20グーリー/入ロポータル

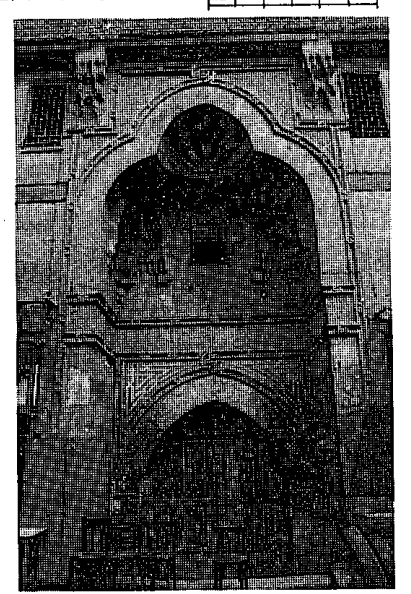

図-21 カーイトバーイ

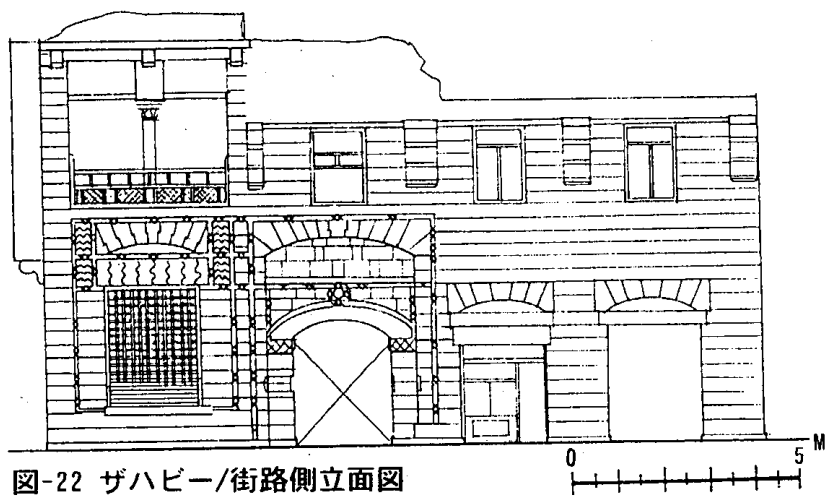


ールトに変わる。さらに言えば、半円形アーチをモールディ ング状に重ねる近代の意匠へと変化した。ワカーラの時代 性を最も顕著に表象するものと言えよう。

人口を強調する手法はハーキム・モスクですでにみられ るが、アクマル・モスク(1125年)にみる深い溝を刻んだ上 心の尖頭形ヴォールトの入口ボータルは街路ファサードを 意識したものとして著名である。三葉形ヴオールトのポー タルは、おそらく12世紀末のシリアにおけるムカルナス・ ポータル ${ }^{32}$ に連なるものと考えられる。それは約 1 世紀 遅れて13世紀末頃カイロに導入されたが33)、頂部の半ドー ムと下部のムカルナスからなるもので、しっかりとした三 葉形に縁取られるのは1370年代以降のことであろう ${ }^{34) 。 ク ゙ ~}$ ーリー(No. 45)やクトゥン (33)は、この形式の三葉形ムカル ナス・ポータルである(図-20)。一方、2つのカーイトバー イ(5/46)やザラーキシュ(44)にみる下部が交差アーチによ るもの(隅にムカルナスを伴う)は、現存遺構ではアシュラ フ・バルスバーイのハンカー(1432年)からのことで、その 当時入口ポータルとしては最新の技法・意匠であったはず である（図-21）。モスクなど当時の宗教的モニュメントに 多用されていた三葉形ポータルが、ワカーラにも見られる ことは留意したい。

オスマン朝になると三葉形はまったく姿を消し、かわっ て弓形ヴォールトの門構えがどのワカーラでも用いられる (図-18/22)。三葉形ポータルは、オスマン朝期を通じても スクなどには見られるが35、逆にワカーラでごく普遍的で あった弓形ポータルがそれ以外の建築ではまったく見られ ない。つまり、弓形ポータルはオスマン朝期ワカーラに固 有のものであった。さらに、この時代のファサードに特徽 的なのは上階の張り出しである。上階部分を街路側に張り だすことはマムルーク朝期から見られたが、オスマン朝期 には石造の持送りを規則的に配して、より大きく $1 \mathrm{~m}$ 以上 張り出すようになった。さらに18世紀以降ではシャラーイ ビー(No. 48/図-8)やナフィーサ(49)などのように、入口上 部を特に強調する意匠まで現れる。マムルーク朝からオス マン朝にかけて共通していたのは、入口周囲の壁面に施さ れた結び目つき紐状装飾带 ${ }^{36)}$ と、入口両脇のムカルナス状 柱頭飾りである。

\section{5.むすび}

以上のように、カイロに現存するワカーラについて、時 代をおって、その建築的特徵を明らかにすることができた。 経済的な衰退期にはいった14世紀後半に、マムルーク朝ス ルターンらによってカイロ市内に隊商交易を管理する施設 が建設され、やがてそれがワカーラと呼ばれるようになっ た。限られた現存遺構からでは断定的には言えないが、あ る程度の規模で、形態的にすでに整っていること、中心軸 に入口を構えること、交差ヴォールトや三葉形ポータルな ど当時の宗教的モニュメントと同じ意匠や技法が使われて
いたことなどから、マムルーク朝期に建設されたワカーラ は、公的な性格が強い建築であったと推測される。交易活 動を奖励する一方、収益を直接吸い上げる目的をも担って いたのであろう。

16世紀になると、ナイル河畔のブーラーク地区が商業的 に脚光をあび、オスマン朝のワーリーたちは相継いで巨大 なワカーラを建設し、上述のような公的な役割はカイロ旧 市街からかなり移されたのではないかと思われる。そこで はマムルーク朝期ワカーラとは異なる様式が採用された。

17世紀以降、依然、支配者による大規模ワカーラも商業 需要に応じて建設されていたが、一方ではより小規模で一 般的なものが数多く建設されるようになった。このことは 家族ワクフが広い階層にまで浸透し、ワカーラ建築がその 対象となったことを反映するものと考えられる。建築形態 的には、アルコーブつきの房室、交差ヴォールトの入口通 廊、弓形の入口ポータル、上階の大きな張り出しなどが統 一的に用いられた。アルコーブの採用が商品陳列など店舗 機能を必須条件としていたことを示唆するほか、弓形ポー タルは固有の形態としてワカーラという建築種別を表示し、 大きな張り出しは高密な市街における複合的都市施設とし ての性格をよく示す。

18世紀にも基本的な構成は踏襲されるが、そのなかで均 等配列による半円形のアーチやヴォールトなどが用いられ るようになった。19世紀以降、平面構成はより規則的なも のとなり、装飾的な付け柱や半円形モールディングなど、 これまでとは異なる意匠が導入された。

現在ではその多くが失われ、遭存するとしてもまったく 不完全な姿となってしまっている。かつては商業活動の中 心的役割を果たしていたワカーラは、いまだ一部に伝統的 商習慣などを残すとはいえ、ワクフ制度の崩壊など近代に おける社会的激変をまともに受けてしまった。

\section{謝 辞}

本研究は、平成 6 年度日本学術振興会力イロ研究連絡七 シター派遣研究員ならびにカイロ・アメリカン大学客員研 究員として行った調查による成果である。カイロ滞在中、 多くの方々のご支援、ご協力をいただいた。アメリカン大 学イスラーム美術・建築学教授ジョージ・スキャンロン氏、 マシュラビーヤ研究所アサド・ナディム氏には諸事にわた りお世話いただいた。お茶の水女子大学助教授三浦徹氏、 プロバンス大学名誉教授アンドレ・レイモン氏、アメリカ ン大学教授ネリー・ハンナ氏には直接テーマに関すること でご教授いただき、きわめて貴重であった。また、エジプ ト考古庁への調查許可などでは中近東文化センター主任研 究員川床睦夫氏をはじめ、現地スタッフであるハーフィー ズ氏、オマル氏に搰折りいただいた。記して、心からの 感謝の気持ちに代えさせていただきたい。 
注

1）そのほか隊商交易に関わる建築は「キャラバンサライ kârwansaray」 「ハーン khan」「マンジル manzil」、「フンドゥク funduq」「リバ ート ribaț、「サムサラ samsara」なよ゙、各地で異なった呼称をもつ。 キャラバンサライはベルシア、トルコで一般的に用いられる。ハーン も広く用いられる言葉で、アラビア語碑銘における初出例は 13 世紀は じめであり(1213年, RCEA, No. 3720)、都市内の倉豍·取引所として盛 んに用いられるのは13世紀の後半以降のことである。マンジルという 語は古いアラビア語文献に見られるが、今日ではほとんど使われない。 マグリブ地方で一般的であるフンドゥクは、この種の施設を表す最も 古い用語と言われる。リバートはイスラーム拡張期にその最前線に設 けら机た軍事的色彩の強い、布教のための拠点となる施設で、特にイ ランや中央アジアなど東方圈で用いられた。サムサラはイェインなど での呼称として知られ、他に「ヤームyâm」「ティームtim、ティムチェ timcheh」はイラン・中央アジアで用いられる。なお、17世紀以降の西 欧旅行者や商人たちはワカーラを誂って「オカル okal」と呼んだ。

: The Encyclopaedia of Islam, "MANZIL", pp. 454 457; "KHAN", pp. 1010 1017; "FONDUK", p. 945, new edition, E. J. Bril1, 1979

2)レバノン・トリボリの1336年(736AH)のもの; Répertoire chronologique d'Epigraphie arabe (RCEA) ; vol. XV, pp. 60-61, no. 5690/ Raymond, A. ; Artisans et Commerçants au Caire au XVIIIe siecle, Tome I, p. 245, Damas, 1973

3) RCEA ; vol. XIV, pp. 268, no. $5590 /$ Bercham, M. V. ; Matériaux pour un Corpus Inscriptionum Arabicarum; vol. I(CIA Egypte), pp. 180-81, 1894/Raymond;op. cit.,p. 245/しかし、碑文にはハーン khânと記さ れており、この当時まだワカーラが一般的ではなかったことがかかる。

4) Muller, K. ;Die Karawanserai im Vorderen Orient, Berlin, 1920 Sauvaget, J. ; "Les Caravanserails Syriens du Ḥadjdj de Constantinople", Ars Islamica IV, pp. 98-121, 1937/Sauvaget; "Caravanserails Syriens du Moyen-Age", Ars Islamica VI, 1939, pp. 48-55 \& VII, 1940, pp. 1-19/Siroux, H. ; Anciennes Voies et Monuments Routiers de la Région d' Ispahân, Mémoires de IFA0 82, Le Caire, 1971 Siroux, M. : "Caravansérails Seld joucides Iraniens", The Art of Iran and Anatolia from the 11 th to the 13 th century A. D., London, pp. 134-149, 1974/Caste1, G. ; "Caravanserail d' Esna(1695)", Annales Is lamologiques 14, Le Caire, pp. 165-176, 1978 : いず扎 交易路上の郊外型キャラバンサライを扱った論考。また、都市内に所 在する施設を扱ったものはScharabi, H. ; “Drei tradionelle Handels -anlangen in Kairo :Nakalat al-Bázara, Nakâlat Du 1-Fiqâr und Makâlat al-Quțn", Mitteilungen der Deutschen Archäologischen Insti tus Abteilung Kairo 34, Kairo, pp. 391-410, 1980/Aalund, F. ; "The Nakalat Bazar' a", in Islamic Cairo, AARP, London, pp. 35-41/ Yahia, F. : Inventaire Archéologique des Caravanserails de Damas, Aix-en-Provence, n.d./拙稿「モロッコ・フェスにおける都市型隊商 施設(フンドゥク)の建築類型と商業的機能について」旧本建築学会計 画系論文集, 第482号, pp. 199-210, 1996年4月

5) Description de l' Egypte ; 23 vols, Paris, 1809-28

6) 'Ali Pacha Mubarak; al-Khițat al-gadida, 20 vols, Balâq, 188889/このほかに、法廷文書 Mahka浪などが使われている。

7）本稿では「カイロ」を「カイロ旧市街」と「ブーラーク地区」に区別する。 8) Raymond, A. \& Wiet, G. ;Les Marchés du Caire, pp. 260-297, IFA0, le Caire, 1979/合計360件が挙げられている。ただし、付図(Plan V-VI) には計348件だけが位置がしめされている。また、ブーラーク地区に ついては下記に計45件のワカーラが列挙されている。

Hanna, N. ; An Urban Hisory of Bâlâq in the Mamluk and 0ttoman Periods, pp. $66-67$, Fig. 9, IFA0, le Caire, 1983

9）拙稿「カイロの隊商宿・ワカーラの現存状況」日本建築学会大会学 術講演梗概集・1995年 8 月)

10）ワカーラにラブァが複合化された建築形式は、「ワカーラ・ラブァ wakâla-rab' 」と呼ばれる。一般に、建物の下層部は石造のヴォールト
構造で倉庫・店舗など業務用とし、上首部は比較的に薄い棟瓦造壁と 木造床組の構造で居住用之するものである。隊商交易施設と集合住宅 というまったく異なる機能をもつ別個の建物を重ねて4 4 5 啗におよ ぶ高層建筑とすることは、極めて特徽的なことではある。部分的に遺 存するものを含め、わずか29例のワカーラ・ラブァについては、住宅 史・都市史などの視点から稿を改めて論じたい。

11) No. 295, Raymond \& Tiet; op. cit., p. 290/文化財No. 9:文化財No. と は、Egytian Survey Authority; Index to Hohammedan Monuments on the Map of Cairo(1/5000), 1951によるもの。“Āthar No."として緑色 の標札に記されて、建物の壁面に表示されている。以下同様。

12）1階中庭に面する小部屋を「房室」と称することにする。聞き取りに

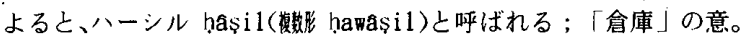
一方、上階の部屋についてはリワーク riwâq、また街路に面するものは ドゥッカーン dukkânよ呼ばれる。

13）房室の前室部分を「アルコーブ」と称する。聞き取りによるよ、アイン ' ain (「目」の意)と呼ばれる。

14）中庭西側および中廊下に面した小室群は十分な採光・換気が得られ ないこと、通廊が中庭に面して壁で仕切られていないこと、通廊の張 出し床を支える石造持送りの意匠が東側のもの之異なること、北西隅 に階段(非現存)があったことなどから、1階同様な゙業務用であったと 考えられる。な拉、中庭の東・南側はラブァの住戸が並んでいる。

15) No. 259, Raymond \& Wiet; op.cit., p. $286 /$ 文化財No. 64

16) Hanna ; op. cit., pp. 94

17) No. 212 , Raymond \& Wiet ; op. cit., p. $281 /$ 文化財No. 397

18）当初は計 15 房室が中庭に面していたと推定される。

19) No. 73 , Raymond \& Wiet; op. cit., p. $267 /$ 文化財No. 411

20) Rifa t Masa Muhammad;al-wakalat wa buyat al-islámiya fi mişr a1-'uthmaniya, a1-Qahi ra, 1993, pp. 110 164

21） 2 階各室は古文曺では八ーシル hâsil と記されており、業務用であ るといっても工房とは限らない。1階と同じ倉庫・店舗・事務所ある いはここを利用する旅商人の宿泊室であった可能性もある。

22) No. 75 , Raymond \& $\mathbb{T i}_{\text {iet }}$; op.cit., p. 267-68

23) No. 313 , Raymond \& Tiet; op. cit., p. $292 /$ 文化財No. 460

24) No. 270, Raymond \& Wiet; op.cit.,p. 288(この建物は1820年に破却) /文化剘;No. 604(ファサードのみ)

25) a1-haiya al-maşrîya al-' âma 11-1-misâha(Egytian Survey Autho -rity):kharița al-qâhira, 1:500, c. 1938 45

26) Raymond, A. ; Le Caire, Paris, 1993, pp. 253 262

27) Herzfeld, E. ; "Damascus : Studies in Architecture-II", Ars Islamica, vol.X, New York, 1968, pp. 13 30

28）旧市街の郊外カラーファ(墓地)内に所在するスルターン・イーナー ルの複合体 $(1451-56)$ 内にみられる(文化財NNo. 158)。

29) Coste, P. ; Architecture Arabe ou Monuments du Kaire, mesures et dessinés de 1818 a 1825 , Paris, 1839, Pl.x XVIII

30) ズール・フィカール(№.13)、サイード(21)、ガンブラート(60)などの 入口通廊は屈曲している。

31) アイユーブ朝創建のシタデルの城門(1176年〜)のほか、ザイン・アッ ディーン・ユースフのザーウィア (1298年/文化財NNo. 172) の入口の間、 サラールとサンガル・ガウリーの廟とマドラサ(1303-4年/文化財No. $221)$ 廟背後の回廊などにみられる。

32）最古例アレッボのマドラサ・シャードバフト(1193年)に始まるムカ ルナス(スタラクタイト)・ポータルの発展は、Creswe11, K. A.C. ; The Muslim Architecture of Egypt, vol. 2, 1952/1978, pp. 146-48

33) ザィン・アッディーン・ユースフのザーウィア(1298年)がカイロ現存 遭構では初出例。

34) アッサンブガー・モスク（1370年/文化財NNo. 185)においてムカルナス・ ボータルは正面に三葉形の枠取りがつく。これ以降のムカルナス・ボ ータルはほぼ例外なく、このような枠取りをもつ。

35）例えば、マフムーディーヤ・モスク(1568年/文化財NNo. 135)をはじめ、 オスマーン・カトフダー・モスク(1734年/文化財NNo. 264)など。

36）聞き取りによると、この装飾帯は“'geft 1 ấab”と呼ばれる。

(1996年 3 月 10 日原稿受理，1996年 7 月17日採用決定) 